\title{
„Kochać życie piękne i młode" - marksistowska i eugeniczna pedagogika Władysława Spasowskiego. Założenia i krytyka personalistyczna
}

W okresie dwudziestolecia międzywojennego obecny był w Polsce nurt myślenia o wychowaniu inspirowany ideologią marksistowską. Wizja przyszłości nakreślona przez Karola Marksa i Fryderyka Engelsa, nazywana marksistowskim komunizmem, jest ,wizją królestwa wolności, pojmowanego jako kolektywna kontrola władzy publicznej nad całą sferą produkcji i wymiany oraz urzeczywistnienia w ten sposób ideału wolności jako świadomego panowania nad zbiorowym losem"1. Najwyższą wartość stanowi w niej idea równości i sprawiedliwości społecznej, rozumianej jako zanik społeczeństwa klasowego i zniesienie własności prywatnej środków produk$\mathrm{cji}^{2}$. Z perspektywy personalistycznej u podstaw marksistowskiego komunizmu stoi błąd filozoficzny i antropologiczny, późniejsi zaś teoretycy (neo)-

* Mgr Justyna Legutko jest doktorantką w Instytucie Pedagogiki Uniwersytetu Jagiellońskiego w Krakowie, w Zakładzie Pedagogiki Szkoły Wyższej i Polskiej Myśli Pedagogicznej. Adres: Instytut Pedagogiki Uniwersytetu Jagiellońskiego, ul. Batorego 12, 31-135 Kraków; e-mail: jlegutko2@gmail.com.

${ }^{1}$ Andrzej Walicki, „Rewolucja październikowa jako projekt komunistyczny”, w: Totalitaryzmy XX wieku. Idee, instytucje, interpretacje, red. Wiesław Kozub-Ciembroniewicz (Kraków: Wydawnictwo Uniwersytetu Jagiellońskiego, 2010), 123.

2 Stanisław Kowalczyk, „Marksizm”, w: Powszechna Encyklopedia Filozofii, t. 6, red. Andrzej Maryniarczyk (Lublin: Polskie Towarzystwo Tomasza z Akwinu, 2005), 857-858. 
marksizmu, jak Antonio Gramsci, stosują manipulację jako metodę walki do wprowadzenia nowego ustroju społecznego ${ }^{3}$. W koncepcji Marksa „słaba jednostka ludzka nie rości sobie już żadnych pretensji do podmiotowości i suwerenności, abdykuje i wyrzeka się siebie na rzecz człowieka kolektywnego"4. Obecny w marksizmie redukcjonizm w postaci jednostronnej materialistycznej interpretacji jednostki implikuje niewłaściwy sposób postrzegania sfery społecznej, rodzinnej czy procesów wychowania i nauczania.

Marksistowska wizja człowieka i świata znajdowała aprobatę w przekonaniach niektórych pedagogów - jednym z nich był Władysław Spasowski ${ }^{5}$. Wyrażając swoje preferencje, Spasowski uznaje, że ,przebieg rozwoju społeczeństwa i kultury ludzkiej prowadzi nieuniknienie do materialistycznego pojmowania dziejów w duchu teorii wielkiego rewolucyjnego socjologa i historiozofa, Karola Marksa, i jego wielkich uczniów i kontynuatorów Engelsa, Lenina i innych"6. Wprowadzenie komunizmu w Rosji nazywa zaś „wschodem wspaniałego słońca wielkiej, największej w dziejach rewolucji"'. Wizja idealnego ustroju społecznego, jaką kreśli, to jedno wielkie społeczeństwo, funkcjonujące bez instytucji państwa, oparte na pracy i współdziałaniu wszystkich jego członków ${ }^{8}$ oraz pozbawione własności prywatnej - przyczyny niesprawiedliwości i przeszkody w pełnym rozwoju kolektywistycznych ideałów9 9

W swych dziełach Spasowski ogłasza aprobatę dla komunizmu w wersji Marksa i Lenina, widząc w nim jedyną drogę do wyzwolenia człowie-

3 Wojciech Chudy, Społeczeństwo zakłamane. Esej o społeczeństwie i kłamstwie (Warszawa: Oficyna Naukowa, 2007), 169-170.

4 Tomasz Ożóg, „J. Maritaina koncepcja wychowania człowieka”, Roczniki Nauk Społecznych KUL 2 (1993): 5-6. T. Ożóg powołuje się na J. Maritain, Humanizm integralny, Warszawa 1981, 15-20.

5 Władysław Spasowski (1877-1941), pedagog, teoretyk wychowania, filozof marksistowski, działacz lewicy nauczycielskiej, członek „Nowych Torów”; 1920-30 dyrektor Państwowych Kursów Nauczycielskich w Warszawie. http://encyklopedia.pwn.pl/haslo/Spasowski-Wladyslaw;3978044.html (dostęp: 9.12.2016).

${ }^{6}$ Władysław Spasowski, Wyzwolenie człowieka $w$ świetle filozofii, socjologii pracy $i$ wychowania ludzkości (Warszawa: Nakładem F. Hoesicka, 1933), 156.

7 Władysław Spasowski, Z.S.R.R. rozbudowa nowego ustroju (Warszawa: Wydawnictwo Jakuba Przeworskiego, 1936), 16.

${ }^{8}$ Spasowski, Wyzwolenie, 272.

9 Tamże, 291. Spasowski odwołuje się do Karola Marksa i Fryderyka Engelsa, „O prawie”, 441 (nie podaje szczegółowych informacji na temat źródła). 
ka. Potwierdzenie takiej interpretacji stanowiska Spasowskiego znajdujemy u Bogdana Nawroczyńskiego, piszącego też, że zalecając usunięcie nierówności przez komunizm, Spasowski ,jak gdyby nie dostrzegał zupełnego zaniku wolności w zrealizowanym już ustroju bolszewickim"10.

\section{1. „Wyzwolenie człowieka” jako społeczno-pedagogiczny testament Wladysława Spasowskiego}

Wszystkim pragnącym rozwiązać wielkie kwestie społeczne, a zwłaszcza pedagogom, Spasowski zostawił testament w postaci książki Wyzwolenie człowieka $w$ świetle filozofii, socjologii pracy $i$ wychowania ludzkości (Warszawa 1933). Dzieło to spotkało się z wielką aprobatą sympatyków marksizmu i krytyką personalistów, zwłaszcza katolickich. Pozytywne recenzje otrzymało od Janiny Zajchowskiej oraz pisma Dziennik Poranny ${ }^{11}$. Współcześnie m.in. Danuta Drynda uznaje, że zawiera ono zasady uspołecznienia, demokracji oraz wolności i jest wartościowe, zwłaszcza pod kątem wychowania młodych ludzi ${ }^{12}$. Nieprzychylnie do książki odnieśli się Walery Jasiński, uznając za „chore” wydanie jej jako testamentu dla nauczycieli ${ }^{13}$, oraz Bogdan Nawroczyński, twierdząc, że łączy ona „przekonania komunistyczne z ideałami osobowości i swobody" ${ }^{14}$. Adam Uziembło ${ }^{15}$ oraz Ludwika Dobrzyńska-Rybicka ${ }^{16}$ wystawili Wyzwoleniu czlowieka negatywne recenzje, za które po latach zostali skrytykowani w pracy Dryndy ${ }^{17}$. Krytyczną ocenę znajdujemy także u Jana Kuchty w książce wydanej w obliczu II woj-

10 Bogdan Nawroczyński, Polska myśl pedagogiczna. Jej główne linie rozwojowe, stan współczesny i cechy charakterystyczne (Lwów-Warszawa: Książnica-Atlas, 1938), 217.

11 Walery Jasiński, O katolicką pedagogikę w Polsce (Katowice: Księgarnia Katolicka, 1938), 14-15.

12 Danuta Drynda, Pedagogika Drugiej Rzeczypospolitej, warunki, orientacje, kontrowersje (Katowice: Wydawnictwo Uniwersytetu Śląskiego, 1987), 140.

13 Jasiński, O katolicką, 14-15.

14 Bogdan Nawroczyński, Współczesne prądy pedagogiczne (Warszawa: Nasza Księgarnia, 1936), 17-19.

15 Adam Uziembło, ,Wyzwolenie człowieka”, Człowiek w Polsce 5 (1934) - za: Drynda, Pedagogika, 137.

16 Ludwika Dobrzyńska-Rybicka, ,Wyzwolenie człowieka jako zagadnienie wychowawcze", Kwartalnik Pedagogiczny" 2-3 (1935) - za: Drynda, Pedagogika, 137.

17 Drynda, Pedagogika, 137. 
ny światowej ${ }^{18}$ oraz po części w przedwojennym wydaniu książki Ludwika Chmaja ${ }^{19}$.

Po II wojnie światowej zostało wydanych wiele opracowań twórczości Spasowskiego, które niestety nie odzwierciedlają rzeczywistej jego koncepcji z powodu pominięcia wielu jej elementów i/lub ,złagodzonej” ich interpretacji. Skutkuje to między innymi bezkrytycznym, błędnym zaliczaniem go do pedagogów personalistycznych, będącym niejako konsekwencją wątpliwej kwalifikacji Chmaja ${ }^{20}$.

\section{Założenia antropologiczne pedagogiki Wladysława Spasowskiego}

Spasowski jest zwolennikiem filozoficznej koncepcji materializmu historycznego Marksa i Engelsa. W swych dziełach neguje on istnienie Boga, a człowieka uznaje za egzemplarz gatunku, rezultat całokształtu stosunków społecznych oraz ,zwierzę, obdarzone przede wszystkim zdolnością wyrabiania na wzór swojej własnej maszyny cielesnej"21. Dla Spasowskiego inteligencja ,wyrabia się" w gromadzie - czego dowodem mają być zwierzęta najbardziej uspołecznione i inteligentne (mrówki, papugi, małpy) ${ }^{22}$, pełną osobowością jest zaś ,wszechstronnie rozwinięty człowiek, uzdolniony do twórczości i przygotowany do twórczego życia w społeczeństwie (...) osobnik uspołeczniony, znajdujący dobro i szczęście najwyższe w dążeniu do dobra wspólnego dla wszystkich"23. Nie zawsze jednak człowiek uspołeczniony jest pełną i prawdziwą osobowością - o czym pisze Chmaj, odwołując się do Spasowskiego ${ }^{24}$. W koncepcji, jaką prezentuje Spasowski, nie ma mowy o indywidualności każdego człowieka, co wynika z postrzegania przez niego jednostki, która jest niczym: „fala, jedna z fal, wpływających z morza zbiorowego i właśnie w związku z tym morzem i jego właściwościami staje się

18 Jan Kuchta, Nowe kierunki i dążenia współczesnej katolickiej pedagogiki (Lwów, 1939), 18-19.

19 Ludwik Chmaj, Kierunki i prądy pedagogiki współczesnej (Warszawa: Nasza Księgarnia, 1938), 227-229.

${ }^{20}$ Ludwik Chmaj, Prady i kierunki w pedagogice XX wieku (Warszawa: Państwowe Zakłady Wydawnictw Szkolnych, 1963), 18.

${ }^{21}$ Spasowski, Wyzwolenie, 144, 309, 360.

22 Tamże, 298-299.

23 Tamże, 465.

${ }^{24}$ Chmaj, Kierunki i prądy, 227-229. 
najbardziej zrozumiałą"25. Indywidualność ma się objawiać jedynie w pełnej poświęcenia pracy społeczneje ${ }^{26}$.

Wizja człowieka łączy się z postrzeganiem społeczeństwa, które dla Spasowskiego, powołującego się na Marksa i Engelsa, stanowi „żywy, czynny i podległy ewolucji organizm, (...) proces przyrodniczo-historyczny"27. Społeczeństwo to składa się z jednostek niedojrzałych, kierowanych przez popędy, namiętności i tendencje do czynienia zła. Nawet dziecko w oczach Spasowskiego posiada brutalne instynkty (np. instynkt niszczycielski polegający m.in. na czerpaniu przyjemności z dręczenia zwierząt) ${ }^{28}$. W konsekwencji powyższego Spasowski uznaje, że człowiekiem należy pokierować „ku wspólnemu szczęściu” ${ }^{29}$, które utożsamia z ustrojem komunistycznym. Stanowisko, jakie prezentuje, jest sprzeczne z założeniami personalistów; jest dalekie od uznania podmiotowości człowieka, postrzegania go jako istoty świadomej, zdolnej do samoopanowania i samokierowania, a przede wszystkim wolnej w swych decyzjach ${ }^{30}$.

Założenia antropologiczne koncepcji Spasowskiego są tożsame z poglądami Marksa i Engelsa, którzy również uznawali człowieka za egzemplarz gatunku, „zwierzę społeczne” oraz rezultat całokształtu stosunków społecznych $^{31}$. U pierwszych teoretyków marksizmu występuje też zdolność „wyrabiania się” jako czynnik odróżniający człowieka od zwierzęcia, zainteresowanie, czym może stać się człowiek i w jakim stopniu jest on twórcą siebie $^{32}$. Z perspektywy personalistycznej Spasowski redukuje i odrzuca niektóre cechy człowieka (antropologiczny redukcjonizm), kwestionując tym jego osobowo-duchowy wymiar. Godzi to w pełnowartościowość osoby, charakteryzującej się wolnością, rozumnością, indywidualnością i samoistotnością ${ }^{33}$. Podporządkowując jednostkę społeczeństwu ${ }^{34}$, nie dostrzega,

25 Spasowski, Wyzwolenie, 369-370.

26 Tamże, 370-373.

27 Tamże, 157.

28 Tamże, 380-381.

29 Tamże, 271.

${ }^{30}$ Stanisław Kowalczyk, Personalizm: podstawy, idee, konsekwencje (Lublin: Wydawnictwo Katolickiego Uniwersytetu Lubelskiego, 2012), 27, 71-72.

${ }^{31}$ Adam Schaff, Marksizm a jednostka ludzka (Warszawa: Polskie Wydawnictwo Naukowe, 1965), 38, 42.

32 Roger Garaudy, Marksizm a osobowość (Warszawa: Książka i Wiedza, 1950), 18-19.

33 Ignacy Dec, „Personalizm”, w: Powszechna Encyklopedia Filozofii, t. 8, red. Andrzej Maryniarczyk (Lublin: Polskie Towarzystwo Tomasza z Akwinu, 2005), 125.

${ }^{34}$ Spasowski, Wyzwolenie, 360. 
że oba bytowania - społeczne i jednostkowe - zawierają się w sobie wzajemnie ${ }^{35}$, nie jest w stanie uznać - jak personaliści - że to społeczeństwo istnieje dla człowieka, że warunkuje jego prawidłowy rozwój. To osoba, jak pisze Mieczysław Krąpiec, góruje nad społeczeństwem „dzięki swej zupełności, godności i podmiotowości wobec praw"36. Mimo że Spasowski stawia społeczeństwo ponad jednostką, powołując się na Lenina, opowiada się za odpowiedzialnością osobistą: „,narody muszą być wspólne a odpowiedzialność osobista" ${ }^{\prime 3}$.

Człowieka sprowadza Spasowski do wymiaru społeczno-ekonomicznego, co potwierdza między innymi stwierdzeniem: „,elem tedy wszelkiej organizacji społecznej winna być świadoma solidarność w pracy dla osiągnięcia jak najpomyślniejszych ekonomicznych i kulturalnych warunków rozwoju człowieka, jako coraz doskonalszej, bardziej uspołecznionej osobowości twórczej" ${ }^{38}$. W konsekwencji powyższego na pierwszym miejscu stawia pracę, to w niej widzi ,najwyższą wartość, która tworzy inne wartości” 39 , ona jest fundamentem „duchowego" życia społecznego i warunkiem powstania nowego typu człowieka ${ }^{40}$. Spasowski formułuje też definicję pracy, uznając za nią „wszelki celowy wysiłek mięśniowy, wydatek energii nerwów i mózgu, który ma na celu pożytek, wszelka praca jest czynnością psychofizyczną, każdemu rodzajowi pracy towarzyszy wysiłek myślowy"41. Nie odróżnia przy tym pracy fizycznej od umysłowej, co dla personalistów jest założeniem niewłaściwym ${ }^{42}$. Podporządkowując osobę pracy, Spasowski nie dostrzega, że ma ona służyć człowiekowi w doskonaleniu, poznawaniu i ,uprawianiu” świata dla dobra własnego, samorealizacji oraz tworzenia kulturalnych i materialnych wartości (ma też uwzględniać cele społeczne). Zatem traktowanie pracy jako najwyższej wartości, jej absolutyzacja, stanowi formę jej wynaturzenia ${ }^{43}$.

Przypisywanie tak dużego znaczenia pracy jest konsekwencją rozumienia rozwoju człowieka jako jej funkcji. Spasowski, odwołując się do En-

\footnotetext{
${ }^{35}$ Czesław S. Bartnik, Osoba i personalizm (Lublin: Standruk, 2012), 19-20.

36 Dec, „Personalizm”, 126.

37 Spasowski, Wyzwolenie, 264.

38 Tamże.

39 Tamże, 159-160.

40 Tamże, 250, 253.

${ }^{41}$ Tamże, 162-163.

42 Kowalczyk, Personalizm, 97.

43 Tamże, 99-101.
} 
gelsa ${ }^{44}$, opowiada się za autokreacją człowieka w wyniku pracy. Twierdzi, że wszystko, czym się człowiek stał, zawdzięcza właśnie jej, a świadome przystosowanie się do przyrody robi z niego

istotę czynną, powstałą z pracy i dzięki pracy rozwijającą się stale, istotę plastyczną i społeczną, gdyż sama praca jest na wskroś społeczną. (...) Przybierając stojącą postawę człowiek wykorzystywał swe ręce do pracy i walki. Stały się one z czasem nie tylko organem jego pracy, ale produktem tej pracy: stopniowo się doskonaliły. (...) Proces pracy rąk i współpracy z innymi wpłynął też na rozwój mowy, rozwój zmysłów i rozwój mózgư ${ }^{45}$.

Zwolennikami autokreacji człowieka w wyniku pracy są również: Marks, twierdzący, że współczesnego homo sapiens - produkt historycznego rozwoju - stworzyła praca, pozwalająca mu przekształcać obiektywną rzeczywistość, a w konsekwencji siebie ${ }^{46}$, oraz (neo)marksista Gramsci, postrzegający jednostkę jako ,proces swoich czynów” ${ }^{47}$. Podzielanie powyższych poglądów przez Spasowskiego jest sprzeczne z antropologią personalistyczną, według której praca jest pochodną natury ludzkiej i została stworzona przez człowieka. Dzięki niej, posługując się rozumem i wolną wolą, człowiek ma możliwość aktualizowania i realizacji zawartych w swojej naturze zdolności, możliwości, zainteresowań, a także uzdolnień i wartości ${ }^{48}$.

Pragnąc wyswobodzić człowieka z ,więzów etyki”, Spasowski odrzuca trwałe zasady etyczne i prawa człowieka, uznając je za konwencję powstałą dla potrzeb ludzkich, a w ich miejsce postuluje sformułowanie nowych, opartych na instynkcie społecznym, intelekcie i zdrowiu fizycznym jednostki - moralność w jego ujęciu polega przede wszystkim na kierowaniu się rozumem $^{49}$. Spasowski jest przy tym zwolennikiem etyki sytuacyjnej - odwołując się do Marksa i Lenina, za dobro uznaje wszystko, co służy budowaniu ustroju komunistycznego, a za zło to, co go hamuje. Odrzuca też szczęście, jakie osoba znajduje w osiąganiu i posiadaniu kultury moralnej, upatrując go, wraz z sensem życia, we wszechstronnym rozwoju i pracy twórczej, a także

${ }^{44}$ Spasowski odwołuje się do Fryderyka Engelsa, Der Anteil der Arbeit an der Menschenwerdung des Affe (nie podaje szczegółowych informacji na temat źródła).

45 Spasowski, Wyzwolenie, 143-144.

${ }^{46}$ Schaff, Marksizm, 43.

47 Antonio Gramsci, Pisma wybrane, t. 1 (Warszawa: Książka i Wiedza, 1961), 38.

${ }^{48}$ Kowalczyk, Personalizm, 97-98.

49 Spasowski, Wyzwolenie, 302-305, 392. 
współdziałaniu i walce o wspólnotowe ideały ${ }^{50}$. Spasowskiego rozumienie moralności stoi w sprzeczności z zasadami personalizmu, według których moralność stanowi podstawę życia osoby: współtworzy ją, konstytuuje oraz doskonali i spełnia ${ }^{51}$. Z kolei zanegowanie trwałych zasad etycznych, co czyni Spasowski, prowadzi do wielu negatywnych konsekwencji zarówno dla jednostki, jak i społeczeństwa, m.in. do rozchwiania moralnego, przyjmowania niewłaściwych postaw czy utraty sensu życia ${ }^{52}$.

Za zasadę naczelną w życiu społecznym Spasowski uznaje „nie miłość dla każdego człowieka, ale miłość pierwiastków dobra, piękna, mądrości i szlachetności, tkwiących w człowieku, miłość ludzi dobrej woli (...), miłość ideału człowieka i nadczłowieka" ${ }^{3}$. Łącząc nienawiść z miłością, „nienawiść do złego jest niezbędnym uzupełnieniem miłości, kto nie umie nienawidzić, nie umiał też kochać", w następnym zdaniu nakłania do wrogości i zwalczania „bydlaków ludzkich” (m.in. kapitalisty, kłamcy, głupca, chama duchowego) -,,objawy zła, głupoty i zbrodni można i należy nienawidzić, a ich nosicieli zwalczać i unieszkodliwiać, jak wszelką inną truciznę i zło" 54 . Krytycznie odnosi się też do dobroczynności publicznej, uznając ją za ,próbę zamaskowania gnojącej się rany społecznej, wyrzut sumienia ludzi sytych"55. Powyższa postawa Spasowskiego pozbawiona jest szacunku dla niezbywalnej godności, jaką posiada każdy człowiek, co jest sprzeczne z zasadami personalizmu i etyką katolicką. Zdaniem Chmaja, idealny człowiek Spasowskiego ,gotów jest z taką samą zaciekłością zwalczać obrońców wiary religijnej, z jaką niektórzy zbyt gorliwi wyznawcy tejże wiary tępili dotąd wszelką propagandę antyreligijną" ${ }^{56}$.

\section{Uwielbienie dla życia młodego}

Na poglądy Spasowskiego nie była bez wpływu popularna w ówczesnym czasie eugenika. Zachwala on świat ,zaczynający rozumieć, że dzięki dotychczasowemu bezładnemu, bezplanowemu i niechlujnemu sposobowi

\footnotetext{
50 Tamże, 304-305, 309-311.

51 Bartnik, Osoba, 70.

${ }^{52}$ Kowalczyk, Personalizm, 117.

${ }^{53}$ Spasowski, Wyzwolenie, 305-306.

54 Tamże, 306.

55 Tamże, 233.

${ }^{56}$ Chmaj, Kierunki i praqdy, 227-228.
} 
rozmnażania się napłodziło się tyle typów wstrętnych fizycznie, brzydkich, ułomnych, chorowitych i złych" 57 . Z perspektywy personalistycznej kwestionuje tym godność osób niepełnosprawnych i chorych. Poprzez zracjonalizowanie rozrodczości chce Spasowski zastąpić ilość dzieci ich jakością. Wymienia również zadania, jakie ma do spełnienia eugenika i jej propaganda:

wskazywać warunki uszlachetnienia rasy ludzkiej przez odpowiedni świadomy antropologiczny dobór jednostek i wytworzenie typów ludzkich o wyższej wartości, walka ze zwyrodnieniem rasy i ze zbyt częstymi porodami, budzenie świadomości społecznej i poczucia obowiązku moralnego względem potomstwa, krzewienie poglądu, że piękno i zdrowie są podstawowymi warunkami moralności i istotnym obowiązkiem wobec społeczeństwa, że nie ma małżeństwa poza miłością i nie ma $\mathrm{w}$ ogóle dzieci nieprawych, są zaś tylko nieprawi rodzice, gdy nie posiadają dostatecznych kwalifikacji na rodzenie zdrowych i dzielnych potomków. (...) Eugenika powinna szczepić przekonanie, że społeczeństwo (...) ma prawo do niedopuszczania do skutecznych związków jednostek chorych (...), a nawet ma prawo do kastrowania typów zbrodniczych, matołkowatych, kretynicznych i nieuleczalnie patologicznych [wyróż. - J.L. $]^{58}$.

Jest więc zwolennikiem „twardego" typu eugeniki - jej „zastosowań” doświadczyły narody Europy najdotkliwiej w latach 30. i 40. XX wieku w postaci ich eksterminacji przez Niemcy.

Postulując „ulepszanie” gatunku, Spasowski czyni to z pominięciem godności osoby ludzkiej i nie czyni tego ze względu na jej dobro, lecz ze względu na czynnik specyficznie pojmowanego interesu społecznego. Jest też zwolennikiem swobody w stosowaniu środków antykoncepcyjnych i abor$\mathrm{cji}^{59}$. Nie uznaje zatem autonomiczności nowo poczętego życia, pozbawia je również takiej samej godności, jaką posiada człowiek dorosły. Nie dostrzega, że dziecko jest osobą już w okresie prenatalnym ${ }^{60}$.

Spasowski jest zwolennikiem regulacji urodzeń, na każdy rok proponując konkursy inteligencji, zdrowia i urody, na których będą wybierani przyszli rodzice ${ }^{61}$. Pozbawia więc człowieka prawa do swobody życia rodzin-

\footnotetext{
${ }^{57}$ Spasowski, Wyzwolenie, 291.

58 Tamże.

59 Spasowski, Z.S.R.R., 118-119; zob. też Spasowski, Wyzwolenie, 292.

${ }^{60}$ Bartnik, Osoba, 33-37; zob. też Kowalczyk, Personalizm, 136-138.

${ }^{61}$ Spasowski, Wyzwolenie, 290-294.
} 
nego, prokreacji i wychowania dzieci. Pisząc o selekcji rodziców, narusza elementarne wartości i zasady personalistycznej teorii człowieka: godność, wolność, podmiotowość. W sposób ewidentny odmawia osobie prawa wolności wyboru. Wprawdzie, podobnie jak współcześni mu personaliści ${ }^{62}$, zaleca przygotowanie młodych do rodzicielstwa i małżeństwa, jednak istota tej propozycji zgodna jest ze zredukowaną, a nie personalistyczną koncepcją człowieka. W ramach takiego przygotowania Spasowski proponuje próbne i koleżeńskie małżeństwa, prowadząc do upowszechniania wolnej miłości: „płyną głosy rozsądne słusznie doradzające młodzieży dojrzałej próbne małżeństwa koleżeńskie i ostatecznie miłość wolną, jako rzecz świętą i podstawowe prawo życia, jako nieszkodliwą dla nikogo, a wielce dobroczynną w swych skutkach dla stron zainteresowanych, którym pomaga do pełnego rozkwitu sił psychicznych” ${ }^{63}$. Małżeństwo ma dla niego rację bytu, „dopóki trwa miłość i przywiązanie, dopóki obie strony życzą sobie tego, dopóki jest ono źródłem zadowolenia i dobrobytu fizycznego i duchowego małżonków" ${ }^{\prime 4}$. Dopuszcza je tylko jako umowę prywatną między jednostkami ${ }^{65}$ odwołując się do przepisów wdrażanych w Rosji sowieckiej.

Obecną w naturze selekcję naturalną Spasowski chce przenieść na społeczeństwo, bez niej jawi mu się ono jako środowisko sztuczne ${ }^{66}$. Jest przy tym zwolennikiem promocji życia młodego i jemu nadaje wyższą rangę: ,trzeba kochać życie, ale życie piękne, młode, bujne, obiecujące, twórcze, dzielne, bohaterskie; trzeba je kochać aż do ofiary z życia własnego, jeżeli z jakichś względów w tym kierunku nie może ono się rozwijać" ${ }^{67}$. Po powyższym zdaniu - jakże pięknym, gdy oderwiemy je od kontekstów, w jakich jest wypowiadane - następuje przedstawienie poglądów w kwestii śmierci. W kontekście powyższego jako żelazna konsekwencja jawi się propagowana przez Spasowskiego śmierć na życzenie, sprzeczna z perspektywy personalistycznej, z nietykalnością życia ludzkiego od poczęcia do naturalnego $\mathrm{kresu}^{68}$. Dla Spasowskiego „wręcz dowodem bohaterstwa i świadectwa wielkości ducha,

${ }^{62} \mathrm{~Np}$. Stanisław Podoleński, zob. Janina Kostkiewicz, Kierunki i koncepcje pedagogiki katolickiej w Polsce 1918-1939 (Kraków: Impuls, 2013), 403-420.

${ }^{63}$ Spasowski, Wyzwolenie, 341-342.

${ }^{64}$ Tamże, 289.

${ }^{65}$ Spasowski, Z.S.R.R., 118-119.

${ }^{66}$ Spasowski, Wyzwolenie, 295-296.

${ }^{67}$ Tamże, 310.

68 Wojciech Chudy, Pedagogia godności. Elementy etyki pedagogicznej (Lublin: Towarzystwo Naukowe Katolickiego Uniwersytetu Lubelskiego, 2009), 151-152. 
jest czyn samobójczy ludzi nieuleczalnie chorych lub ostatecznie wyczerpanych życiem, którzy (...) doszli do wniosku, że dalsze ich istnienie staje się męką bezpłodną i jedynie ciężarem dla otoczenia i społeczeństwa" ${ }^{\prime 69}$. Nie ma zatem w jego wizji człowieka miejsca dla człowieka starego, schorowanego, nie ma też szacunku dla starości, kalectwa, niepełnosprawności - dla człowieka, którego życie mija.

\section{Wychowanie i nauczanie}

Poglądy na świat i człowieka stanowią podstawę do formułowania założeń dotyczących wychowania i kształcenia. Spasowski jawi się jako zwolennik ,jednolitego i równego wychowania i nauczania koedukacyjnego", przygotowującego do nowej społeczno-ekonomicznej rzeczywistości ${ }^{70}$. Dokonana przez niego typologia wychowania, na umysłowe, fizyczne i nauczanie techniczne, ma się przyczynić do zwiększenia produkcji społecznej i wytwarzania wszechstronnie rozwiniętych ludzi ${ }^{71}$ - taką typologię oraz cele proponował również w swej koncepcji Marks ${ }^{72}$. Wychowanie w ujęciu Spasowskiego staje się narzędziem do wcielenia ustroju komunistycznego, czego potwierdzenie znajdujemy u Nawroczyńskiego, który ponadto nazywa Spasowskiego pedagogiem socjalistycznym oraz „społeczno-politycznym konstruktorem" postrzegającym wszelki proces wychowania i kształcenia instrumentalnie ${ }^{73}$. Spasowski, narzucając osobie posiadającej wolną wolę zewnętrzne wymogi i dostosowując ją do ustroju, którego jest zwolennikiem, pozbawia ją prawa do bycia sobą. Wprawdzie pisze, że ,nie wolno uważać ludzi teraźniejszych za środek dla osiągnięcia celów i szczęścia pokoleń przyszłych, byłoby to uznaniem jednostki za narzędzie i pozbawieniem jej prawa bycia sobą, prawa godności ludzkiej"'74, ale innymi zaleceniami niweczy to przekonanie. Twierdzi też, że wychowany człowiek ma być „wrogiem wszelkiego porządku społecznego opartego na przemocy, niwe-

\footnotetext{
${ }^{69}$ Spasowski, Wyzwolenie, 316.

70 Tamże, 414-415.

71 Tamże, 421-422.

${ }^{72}$ Karol Marks, Fryderyk Engels, $O$ wychowaniu (Wrocław-Warszawa-Kraków: Wydawnictwo Państwowej Akademii Naukowej, 1965), 284-285.

${ }^{73}$ Nawroczyński, Wspótczesne prądy, 19-20.

${ }^{74}$ Władysław Spasowski, Zasady samokształcenia (Warszawa: Wydawnictwo Michała
} Arcta, 1923), 66. 
lacji jednostek, mechanizacji i upośledzeniu sił ludzkich dla jakichkolwiek aspołecznych, ubocznych celów i względów"75, ale jednocześnie proponuje innego rodzaju przemoc i uprzedmiotowienie.

Przez wychowanie Spasowski pragnie przekształcać ,ruchliwą istotę w człowieka czynu i pracy, gdyż tylko działanie przynosi największą rozkosz, a kto tego nie rozumie, stanowi ciężar dla społeczeństwa"76. Uznając pracę za obowiązkową i powszechną metodę kształcenia i wychowania (wraz z koordynowaniem popędów stanowi ona najważniejszy element w kształtowaniu woli i charakteru), utożsamia z nią nawet zabawę, którą dopuszcza jedynie w początkowym okresie życia. Tu winna odpowiadać zainteresowaniom dziecka ${ }^{77}$. Jest przy tym zwolennikiem stopniowego zwiększania pra$\mathrm{cy}^{78}$ - jak Marks, który dostosowuje ją do wieku, dzieląc wychowanków na trzy grupy ${ }^{79}$. Spasowski pragnąc budować nowy, mocno zorganizowany system społeczny na przymusie pracy: ,wszyscy bez wyjątku muszą pracować, nikt i pod żadnym pozorem nie może się od pracy uchylać"80, już dziecku chce wpajać, że nie może ono pracować tylko wtedy, gdy ma na to ochotę ${ }^{81}$. Założenie to stoi w sprzeczności z zasadami personalizmu. Dla personalistów praca nie jest wyłącznie obowiązkiem człowieka, ale jest też jego prawem, powołaniem, radością i trudem. Stanowi ważny czynnik w kształtowaniu młodego człowieka (uczy samokierowania, wewnętrznej dyscypliny, odpowiedzialności i opanowania), ale nie jest w tym najważniejsza ${ }^{82}$, poza pracą występuje na przykład kształtowanie sumienia moralnego ${ }^{83}$.

Wychowanie w koncepcji Spasowskiego to wychowanie jednolite, społeczne i kontrolowane przez całe społeczeństwo, wynikające z przynależności jednostki do społeczeństwa, które ma się odbywać w specjalnych internatach i instytucjach społecznych ${ }^{84}$. Polega ono „na rozwoju twórczych sił, tkwiących w dziecku oraz dążeniu do rozwoju osobowości ludzkiej w du-

75 Spasowski, Wyzwolenie, 372.

76 Tamże, 345.

77 Tamże, 366, 390-392.

78 Tamże, 414.

79 Marks, Engels, O wychowaniu, 283-284.

${ }^{80}$ Spasowski, Wyzwolenie, 164-165.

81 Tamże, 379.

${ }^{82}$ Kowalczyk, Personalizm, 96, 98-99.

83 Jan Paweł II, Familiaris Consortio (Wrocław: Wydawnictwo Księgarni Archidiecezjalnej, 1994), 15.

${ }^{84}$ Spasowski, Wyzwolenie, 66, 290. 
chu syntezy indywidualizmu i socjalizmu, w duchu wspólnoty pracy i całego rodzaju ludzkiego, w duchu powszechnego solidaryzmu pracy $\mathrm{z}$ hasłem opanowania przyrody dla wspólnego szczęścia wszystkich ludzi na ziemi. Wychowanie od najmłodszych lat ma wpajać ideały socjalistyczne i kolektywistyczne, opierając je na mocnym, realnym gruncie, powinno zaszczepić (...) solidaryzm pracy, (...) gotowość do oddania społeczeństwu swych talentów i nawet swego życia"85. Spasowski, odwołując się do Marksa, za fundament wychowania uznaje ,poznanie wytwórczości i pracy ludzkiej, narzędzi pracy i stosunków społecznych" ${ }^{\text {" }}$. Takie rozumienie wychowania jest bliskie pierwszym teoretykom marksizmu, a dalekie od interpretacji personalistycznej. Dla personalistów wychowanie (ściśle związane z samowychowaniem) jest pokazywaniem i unaocznianiem podopiecznemu godności osobowej oraz nakierowywaniem go na tę wartość, a także wchodzeniem w dialog międzyosobowy (z drugą osobą, ze sobą i z Bogiem) ${ }^{87}$. Podopieczny jest podmiotem tego procesu - posiada podmiotowość metafizyczną (jest faktem) oraz funkcjonalną, rozwijającą się w ciągu życia i stanowiącą jeden z celów wychowania. Podmiotowość funkcjonalna polega na zdolności nieulegania impulsom władz zmysłowym oraz dotyczy zdominowania umysłu przez różne ideologie ${ }^{88}$.

Będąc $\mathrm{z}$ jednej strony zwolennikiem internacjonalizacji wychowania i wychowania pacyfistycznego, z drugiej sprzeciwia się Spasowski wychowaniu rodzinnemu. Uznaje, że „fachowa i życzliwa opieka wychowawcza stanowczo jest lepsza od dyletanckiej i kapryśnej opieki rodzicielskiej”"89. Dzieci chce wyzwolić spod autorytetu rodziców - co jest tożsame z poglądami teoretyków marksizmu, przyznającymi dziecku takie same prawa, jak ich rodzicom ${ }^{90}$. Wzoruje się prawdopodobnie na rozwiązaniach bolszewików wprowadzających w Rosji prawo odbierające rodzicom dzieci oraz „uniezależniające” dzieci od rodziców i odwrotnie ${ }^{91}$. Spasowski nie dostrzega zatem wartości wychowania rodzinnego, tak ważnego dla personalistów,

${ }^{85}$ Tamże, 362-363.

86 Tamże, 457.

${ }^{87}$ Chudy, Pedagogia, 58-61.

88 Jarosław Horowski, „Podmiotowość w pedagogice chrześcijańskiej o inspiracji tomistycznej”, Paedagogia Christiana 2/24 (2009): 66-67, 72.

89 Spasowski, Wyzwolenie, 290.

${ }^{90}$ Karol Antoine, „Szkoła socjalistyczna”, w: Socjalizm i komunizm potępiony przez papieży, red. Aneta Maniecka (Sandomierz: Wydawnictwo Diecezjalne, 2009), 282.

${ }_{91}$ Stanisław Podoleński, Rodzina w sowietach (Kraków: Wydawnictwo Księża Jezuici, 1938), 18-19. 
polegającego na wzajemnym obdarowywaniu się człowieczeństwem i byciu autentycznym ${ }^{92}$. Nie uznaje rodziny za pierwowzór wszystkich relacji społecznych (w niej osoba przyswaja sposoby życia, myślenia oraz wzory postępowania), nie dostrzega, że jej brak w konsekwencji przyczyni się do powstawania egoistycznych, antyspołecznych i destruktywnych postaw ${ }^{93}$. Sprzeciwiając się wychowaniu rodzinnemu, Spasowski pozbawia rodziców naturalnego prawa do wychowania swego potomstwa. Jako prawo naturalne jest ono niezbywalne i nikt nie może go ,zawłaszczyć”, a zatem instytucje państwa nie powinny przejmować obowiązków wychowawczych rodziców, ale jedynie pomagać im w ich wypełnianiu ${ }^{94}$.

W swej koncepcji Spasowski dużą wagę przykłada do pozbawienia wychowanka przymusu w jego aktywności, ale rozumie to jako zaprzestanie wychowania religijnego ${ }^{95}$ - całościowo chodzi o zaprzestanie narzucania poglądów religijnych, etycznych i myślowych. Uznając za główną pedagogiczną zasadę atmosferę wolności, Spasowski de facto sprzeciwia się traktowaniu dziecka jak wolnej istoty. Twierdząc, że ,wolność zupełna, bezwzględna, jest pojęciem czczym, fantazją"96, chce ,dać dzieciom jasne pojęcie wolności osiągalnej, to znaczy takiej, która nie pozostałaby w sprzeczności z zasadniczymi wymaganiami porządku społecznego opartego na współpracy wszystkich, (...) nauczyć je rozumieć, na czym polega istota tego porządku, aby móc w nim upatrywać gwarancje swobód indywidualnych" "97. Takie ujęcie wolności jest bliskie Marksowi i Leninowi postrzegającym ją jako ,uleganie konieczności” ${ }^{98}$ oraz Gramsciemu, który widzi w niej „uznanie konieczności”99. W rzeczywistości tak rozumiana wolność jest zniewoleniem człowieka, pozbawieniem go wolnej woli, zignorowaniem jego podstawowego i niezbywalnego prawa do wolności rozumianej jako „możność nieskrępowanego wyboru wartości, celów życiowych i środków niezbędnych do ich realizacji, (...) zdolność do podejmowania odpowiedzialnych decyzji w konkretnej sytuacji życiowej" (oczywiste jest, że nie może ona kolidować z dobrem wspól-

92 Chudy, Pedagogia, 164-165.

93 Kowalczyk, Personalizm, 147-148.

94 Jan Paweł II, Familiaris Consortio, 67-68.

95 Spasowski, Wyzwolenie, 391-392.

96 Tamże, 381-382.

97 Tamże, 331-332.

98 Stefan Kunowski, Podstawy współczesnej pedagogiki (Warszawa: Wydawnictwo Salezjańskie, 1993), 91.

99 Gramsci, Pisma, 36. 
nym $)^{100}$. Spasowski popiera przy tym teoretyków wychowania stawiających na pierwszym miejscu „uwznioślenie dążeń naturalnych”"101 - co postulowali zwolennicy wychowania liberalnego, jak np. J. J. Rousseau. Domagając się powrotu człowieka do ,natury własnej, do swych instynktów najgłębszych, do swobody wyrazu swych przeżyć i odczuć"102, wolność w wychowaniu sprowadza do obszaru ludzkiej biologii (instynktów, natury), nie zachowuje jej w sferze ducha (kultury). Nie daje odpowiedzi na pytanie: co jeśli instynkty człowieka będą naruszały zasady etyczne?

W celu przygotowania dziecka do uzyskania właściwego wykształcenia Spasowski za konieczne uważa wyzwolenie jego umysłu „z powijaków tradycji, powagi i dogmatu"103, a zwłaszcza uwolnienie od założeniowości teologicznych, poprzez „rozbicie starych tablic” i ,zapanowanie nad przeszłością"104 - myśli zatem tak jak Marks, żądający zburzenia wszystkiego, co podtrzymuje porządek społeczny ${ }^{105}$ oraz budząca uznanie Spasowskiego zwolenniczka marksizmu Stefania Sempołowska ${ }^{106}$. Przytaczając poglądy na religię F. Nietzschego, K. Marksa, F. Engelsa i W. Lenina ${ }^{107}$, uznaje ją za wymysł ludzki powstały na gruncie strachu wynikającego z nieznajomości praw przyrody, „opium dla ludu” oraz przeszkodę w myśleniu i rozwoju, propaguje także laicyzację wychowania i nauczania ${ }^{108}$. Nauczanie religii Spasowski utożsamia wręcz ze zbrodnią: „wykład tak zwanej religii jest najstraszniejszą zbrodnią, jaką tylko można sobie wyobrazić. Katowanie, zabójstwo i gwałcenie dzieci jest niczym w porównaniu z tą zbrodnią" ${ }^{109}$. Ewidentnie ,nie dostrzega wartości życia religijnego i ideałów religijnych dla kultury duchowej" ${ }^{110}$ - jak pisze o Spasowskim Chmaj.

${ }^{100}$ Kowalczyk, Personalizm, 94-96; zob. też: Janina Kostkiewicz, Wychowanie do wolności wyboru. Ponadczasowy wymiar pedagogiki Fryderyka Wilhelma Foerstera (Kraków: Impuls, 2008).

101 Spasowski, Wyzwolenie, 380-384.

102 Tamże, 373.

103 Spasowski, Zasady samoksztatcenia, 51.

104 Spasowski, Wyzwolenie, 29, 77.

105 Karol Marks, Fryderyk Engels, O religii (Warszawa: Książka i Wiedza, 1962), 29.

106 Stefania Sempołowska, Pisma pedagogiczne i oświatowe (Warszawa: Państwowy Instytut Wydawniczy, 1960), 105-107.

107 Spasowski, Wyzwolenie, 70-81.

108 Tamże, 35-37.

109 Tamże, 404.

${ }^{110}$ Chmaj, Kierunki i prądy, 227. 
Wychowanie religijne postrzega Spasowski zbyt wąsko, zarzuca mu posiadanie zaledwie jednego celu - religii ${ }^{111}$. Jest to uproszczenie, personalistyczni pedagodzy katoliccy (m.in. J. Kuchta, B. Żulińska, Z. Bielawski, T. Kukołowicz) wymieniają ich wiele, utożsamiając je z celami życia ${ }^{112}$. Stanowisko Spasowskiego jest efektem zredukowanej koncepcji człowieka, w której pozbawiony jest on wymiaru duchowego. Kolejne oskarżenie kieruje Spasowski do duchownych: „olbrzymia większość kleru, tej czarnej, wstecznej międzynarodówki, stale zawodowo uprawia obłudę i fałsz, jedynie kazuistycznie, rzadko i bardzo ostrożnie wypowiada się w sprawie wojny, bynajmniej nie zwalcza kary śmierci, nie walczy też ani z prostytucją, ani z wyzyskiem, ani z pogromami" ${ }^{113}$. W swojej interpretacji rzeczywistości jest zdecydowanie jednostronny. Nie dostrzega treści Ewangelii dotyczących sprawiedliwości społecznej i miłości bliźniego; nie przyjmuje do wiadomości działań podejmowanych dla naprawy niesprawiedliwego ustroju społecznego płynących ze współczesnej mu katolickiej nauki społecznej i zasad personalizmu. Poza papieżami - Piusem IX, Leonem XIII i Piusem XI ${ }^{114}$, działania takie podejmowali: A. Wóycicki, S. Podoleński, kard. S. Wyszyński, J. Piwowarczyk, S. Adamski, M. Sopoćko, S. Abt i wielu innych ${ }^{115}$.

Wizja szkoły, jaką przedstawia w swych dziełach Spasowski, jest adekwatna do bolszewickiej - sam autor nazywa ją szkołą pracy twórczej lub organem wychowania socjalistycznego ${ }^{116}$. Za ,najpiękniejszy” program szkolny Spasowski uznaje program sowiecki, chwaląc jednocześnie marksowski podział programu na dziedziny: przyrodoznawczą, techniczno-wytwórczą i naukę o społeczeństwie ${ }^{117}$. W swej koncepcji proponuje podział szkoły na kilkuletnie stopnie: pierwszy - czteroletni (dla dzieci w wieku 8-11 lat); drugi - pięcioletni (12-16 lat); następnie szkoły specjalne niższe - zawodowe albo dwuletnie studium ${ }^{118}$. Uniwersytety zaś chce przekształcić na szkoły zawodowe o charakterze ,pogłębionym i różnorodnym”"119. System

111 Spasowski, Wyzwolenie, 16-17.

112 Kostkiewicz, Kierunki i koncepcje, 49-55.

113 Spasowski, Wyzwolenie, 222.

114 Socjalizm i komunizm potępione przez papieży, red. Aneta Maniecka (Sandomierz: Wydawnictwo Diecezjalne, 2009), 14-289.

115 Kostkiewicz, Kierunki i koncepcje, 399-404.

116 Spasowski, Wyzwolenie, 421-422.

117 Tamże, 457-458.

118 Tamże, 421-422.

119 Tamże, 435. 
pedagogiczny Spasowskiego, jak pisze Chmaj, ,jednoczy w sobie i zespala tendencje komunistycznej szkoły produktywnej z zasadami szkoły czynnej i szkoły pracy" 120 .

Cel nauczania utożsamia Spasowski ze zrozumieniem zasad i metod badań naukowych, poznaniem współczesnego świata i jego warunków, wytworzeniem badawczego ducha, rozbudzeniem umysłu oraz zamiłowania do postępu i rozwoju w marksistowskim ujęciu ${ }^{121}$. Uznając, jak Marks ${ }^{122}$, za najlepszy wiek do rozpoczynania elementarnej nauki szkolnej dziewiąty rok życia, wcześniej dopuszcza jedynie książki o otaczającym świecie ${ }^{123}$. Jako zwolennik nauki przez praktykę (metoda laboratoryjna), odwołując się do Lenina, sprzeciwia się pamięciowemu przyswajaniu wiedzy i chce je zastąpić badaniem - „wiedza powinna ustąpić miejsca umiejętności zdobywania wiedzy"124. Zwolennikami naukowego poznania świata są również współcześni Spasowskiemu teoretycy humanizmu chrześcijańskiego, pedagogiki personalistycznej i katolickiej ${ }^{125}$, lecz Spasowski tych faktów nie uznaje tak samo jest w przypadku edukacji przez całe życie, której, tak jak oni, jest zwolennikiem. Określone wymogi, zgodne ze swoimi poglądami, Spasowski stawia też wychowawcom, którzy muszą być świeccy i wyzwoleni z dawnych poglądów. Ich zadanie ma polegać na pobudzaniu i rozwijaniu popędów jednostki w taki sposób, aby stała się ona „panem swego losu” 126 . Losu de facto zewnętrznie determinowanego, z założenia podporządkowanego obranej doktrynie ideologicznej.

Za pozytywne wychowawczo Spasowski uznaje wysokie wymagania, ostre nagany, rzadkie pochwały oraz stanowczy ton w kontakcie dorosłego z dzieckiem. „Dobra szkoła to, jak wiemy, twarda szkoła. Tylko taka szkoła rozwija wytrwałość, cierpliwość, stateczność i przekonanie, że każdą rzecz wielką zdobywa się uporem, a często zaparciem się i poświęceniem; uczy nie bać się niedostatku, cierpienia i walki" ${ }^{127}$. Spasowski dopuszcza również karność zewnętrzną, ,gdy prowadzi do wyrobienia siły wewnętrznej, woli

\footnotetext{
120 Chmaj, Kierunki i prady, 227.

121 Spasowski, Wyzwolenie, 450, 452-453.

122 Marks, Engels, O wychowaniu, 284.

123 Spasowski, Wyzwolenie, 465.

124 Tamże, 489.

125 Kostkiewicz, Kierunki i koncepcje, 97-643.

126 Spasowski, Wyzwolenie, 345.

127 Tamże, 393.
} 
jednostki i jej poczucia nieprzekraczalnych granic wolności”'128. Zatem nie ma tu mowy o bezwarunkowym poszanowaniu godności ucznia - co występuje w personalizmie. Spasowski chce zahartowania w realnych warunkach i dlatego sprzeciwia się stwarzaniu „ulepszonego" środowiska wychowawczego, innego niż realia życia i pracy ${ }^{129}$. Poglądy, jakie wypowiada o szkole, są dalekie od uznania jej za wspólnotę nauczycieli i uczniów czy szkołę uczestnictwa - bycia razem z innymi, a jednocześnie bycia sobą poprzez to „razem”" ${ }^{130}$. Wychowanek w szkole Spasowskiego jest traktowany instrumentalnie, jego rozwój jest ściśle związany z jak najlepszym przygotowaniem do przyszłej pracy produkcyjnej i życia kolektywnego, w którym ma funkcjonować niczym element maszyny.

\section{Podsumowanie}

Studiując dzieła Władysława Spasowskiego, bezsprzecznie można go uznać za pedagoga socjalistycznego, respektującego poglądy K. Marksa i F. Engelsa. Klasyfikacji tej dokonano jeszcze przed II wojną światową (B. Nawroczyński, J. Kuchta, W. Jasiński, L. Dobrzyńska-Rybicka), jak i po niej. Powojenne edycje prac Spasowskiego pomijają jednakże najbardziej skrajne, skompromitowane poglądy ${ }^{131}$.

Przyjęty przez Spasowskiego antropologiczny redukcjonizm warunkuje jego pedagogikę. Spasowski przyjmuje marksistowską koncepcję człowieka i interpretuje go w sposób jednostronnie materialistyczny i naturalistyczny. Sprowadza go do wymiaru społeczno-ekonomicznego, wykluczając jego osobowo-duchowy wymiar. Za najwyższą wartość uznaje pracę - stwórczynię człowieka i gwarancję jego dalszego rozwoju. Na niej - jako metodzie - opiera wychowanie i kształcenie. Jest też zwolennikiem aborcji, twardej eugeniki, nie akceptuje dysfunkcji jednostki. Propaguje prawo do macierzyństwa jedynie dla osób ,pięknych i zdrowych”, wybranych w drodze konkursów oraz popiera wolną miłość i małżeństwo na próbę.

128 Tamże, 382.

129 Tamże, 379-382.

${ }^{130}$ Chudy, Pedagogia, 191-194.

131 Władysław Spasowski, Wybór pism pedagogicznych, oprac. Wacław Wojtyński (Warszawa: Państwowe Zakłady Wydawnictw Szkolnych, 1949); Władysław Spasowski, Wybór pism, oprac. Władysław Ozga (Warszawa: Książka i Wiedza, 1949). 
Jako zwolennik ustroju komunistycznego właśnie do niego chce przygotować społeczeństwo, traktując wychowanie i nauczanie instrumentalnie, jako narzędzie służące wdrożeniu obranego ustroju społecznego, a dziecko/ człowieka jako środek do osiągnięcia swych celów. Sprzeciwiając się wychowaniu rodzinnemu i religijnemu, jest zwolennikiem laicyzacji wychowania i wychowania społecznego, które ma się odbywać w specjalnie przygotowanych do tego instytucjach. Ich zadaniem ma być wpajanie wychowankom ideałów socjalistycznych i kolektywistycznych, aby jak najlepiej przygotować ich do przyszłej pracy produkcyjnej. Szkoła w ujęciu Spasowskiego to organ wychowania socjalistycznego i szkoła pracy. Spasowski jest też zwolennikiem dyscypliny i karności w wychowaniu. Swą wychowawczą „miłość” rezerwuje dla „wielbicieli” komunistycznego ustroju społecznego, do pozostałych zaś kieruje nienawiść. Wolność natomiast utożsamia z wyzwoleniem umysłu od założeniowości teologicznych i akceptowaniem konieczności.

Przyjęta w artykule personalistyczna perspektywa oglądu założeniowości zawartej w tekstach Władysława Spasowskiego w sposób jednoznaczny eliminuje go z kręgu pedagogiki personalistycznej. Klasyfikacyjny błąd zawarty w dziele L. Chmaja był - jak pokazują badania J. Kostkiewicz - wskazywany przez personalistów zaraz po jego ukazaniu się $e^{132}$. Interpretacja wyżej dokonana potwierdza brak jakichkolwiek podstaw do kwalifikowania myśli pedagogicznej W. Spasowskiego jako personalistycznej.

\section{„To Love a Beautiful and Young Life" - Marxist and Eugenic Education of Wladyslaw Spasowski: Assumptions and Personalistic Criticism (Summary)}

The aim of this article is to present the Marxist and eugenic pedagogy of Wladyslaw Spasowski. In his concept, Spasowski uses anthropological reductionism, rejects individuality and puts society above a person. In his opinion, work is the highest value with the power of creating people. In fact, the whole of his pedagogy is based on the concept of work. Upbringing and education have to prepare for the communist reality. He endorses social education in special institutions designed to inculcate socialist and collectivist ideals. Whereas religion education and fami-

132 Dominika Jagielska, Janina Kostkiewicz, Pedagogika humanizmu społecznego Andrzeja Niesiołowskiego (Kraków: Wydawnictwo Uniwersytetu Jagiellońskiego, 2015), 259-260. 
ly fostering are considered as harmful to children's development. His educational affection is reserved for "admirers" of values he regards as true. Spasowski also supports the rationalization of reproduction and internationalization of upbringing. The school he proposes is similar to the Bolshevik's school.

Keywords: marxist education; Wladyslaw Spasowski; eugenic; personalistic criticism.

\section{„Kochać życie piękne i młode” - marksistowska i eugeniczna pedagogika Władysława Spasowskiego. Założenia i krytyka personalistyczna (Streszczenie)}

Celem artykułu jest ukazanie marksistowskiej i eugenicznej pedagogiki Władysława Spasowskiego. W swej koncepcji Spasowski stosuje antropologiczny redukcjonizm, odrzuca też indywidualność jednostki, nad którą stawia społeczeństwo. Za najwyższą wartość uznaje pracę, twierdząc, że stworzyła człowieka i na niej opiera całą rzeczywistość, w tym pedagogikę. Wychowanie i nauczanie w jego ujęciu ma przygotować do mającej się zrealizować komunistycznej rzeczywistości. Spasowski popiera wychowanie społeczne odbywające się w specjalnie przygotowanych instytucjach i wpajające ideały socjalistyczne oraz kolektywistyczne. Sprzeciwia się też wychowaniu religijnemu i rodzinnemu, uznając je za szkodliwe dla rozwoju, a swą wychowawczą miłość rezerwuje dla „wielbicieli” wartości, które sam wyznaje. Spasowski jest też zwolennikiem racjonalizacji rozrodczości oraz internalizacji wychowania. Szkoła, jaką proponuje, jest adekwatna do bolszewickiej.

Slowa kluczowe: pedagogika marksistowska; Władysław Spasowski; eugenika; krytyka personalistyczna.

\section{Bibliografia}

Antoine, Karol. „Szkoła socjalistyczna”. W: Socjalizm i komunizm potepiony przez papieży, red. Aneta Maniecka, 288-296. Sandomierz: Wydawnictwo Diecezjalne, 2009.

Bartnik, Czesław S. Osoba i personalizm. Lublin: Standruk, 2012.

Chmaj, Ludwik. Kierunki i prądy pedagogiki współczesnej. Warszawa: Nasza Księgarnia, 1938. 
Chmaj, Ludwik. Prądy i kierunki w pedagogice XX wieku. Warszawa: Państwowe Zakłady Wydawnictw Szkolnych, 1963.

Chudy, Wojciech. Pedagogia godności. Elementy etyki pedagogicznej. Lublin: Towarzystwo Naukowe Katolickiego Uniwersytetu Lubelskiego, 2009.

Chudy, Wojciech. Społeczeństwo zakłamane. Esej o społeczeństwie i kłamstwie. Warszawa: Oficyna Naukowa, 2007.

Dec, Ignacy. „Personalizm”. W: Powszechna Encyklopedia Filozofii, t. 8, red. Andrzej Maryniarczyk, 122-127. Lublin: Polskie Towarzystwo Tomasza z Akwinu, 2005.

Drynda, Danuta. Pedagogika Drugiej Rzeczypospolitej, warunki, orientacje, kontrowersje. Katowice: Wydawnictwo Uniwersytetu Śląskiego, 1987.

Encyklopedia: http://encyklopedia.pwn.pl/haslo/Spasowski-Wladyslaw;3978044. html.

Garaudy, Roger. Marksizm a osobowość. Warszawa: Książka i Wiedza, 1950.

Gramsci, Antonio. Pisma wybrane, t. 1. Warszawa: Książka i Wiedza, 1961.

Horowski, Jarosław. „Podmiotowość w pedagogice chrześcijańskiej o inspiracji tomistycznej". Paedagogia Christiana 2/24 (2009): 63-78.

Jagielska, Dominika, Janina Kostkiewicz. Pedagogika humanizmu społecznego Andrzeja Niesiołowskiego. Kraków: Wydawnictwo Uniwersytetu Jagiellońskiego, 2015.

Jan Paweł II. Familiaris Consortio. Wrocław: Wydawnictwo Księgarni Archidiecezjalnej, 1994.

Jasiński, Walery. O katolicka pedagogike w Polsce. Katowice: Księgarnia Katolicka, 1938.

Kostkiewicz, Janina. Kierunki i koncepcje pedagogiki katolickiej w Polsce 1918-1939. Kraków: Impuls, 2013.

Kostkiewicz, Janina. Wychowanie do wolności wyboru. Ponadczasowy wymiar pedagogiki Fryderyka Wilhelma Foerstera. Kraków: Impuls, 2008.

Kowalczyk, Stanisław. „Marksizm”. W: Powszechna Encyklopedia Filozofii, t. 6, red. Andrzej Maryniarczyk, 855-858. Lublin: Polskie Towarzystwo Tomasza z Akwinu, 2005.

Kowalczyk, Stanisław. Personalizm: podstawy, idee, konsekwencje. Lublin: Wydawnictwo Katolickiego Uniwersytetu Lubelskiego, 2012.

Kuchta, Jan. Nowe kierunki i dążenia współczesnej katolickiej pedagogiki. Lwów, 1939.

Kunowski, Stefan. Podstawy współczesnej pedagogiki. Warszawa: Wydawnictwo Salezjańskie, 1993.

Marks, Karol, Fryderyk Engels. O religii. Warszawa: Książka i Wiedza, 1962. 
Marks, Karol, Fryderyk Engels. O wychowaniu. Wrocław-Warszawa-Kraków: Wydawnictwo Państwowej Akademii Naukowej, 1965.

Nawroczyński, Bogdan. Polska myśl pedagogiczna. Jej główne linie rozwojowe, stan wspótczesny $i$ cechy charakterystyczne. Lwów-Warszawa: Książnica-Atlas, 1938.

Nawroczyński, Bogdan. Wspótczesne prądy pedagogiczne. Warszawa: Nasza Księgarnia, 1936.

Ożóg, Tomasz. „J. Maritaina koncepcja wychowania człowieka”. Roczniki Nauk Społecznych 2 (1993): 5-19.

Podoleński, Stanisław. Rodzina w sowietach. Kraków: Wydawnictwo Księża Jezuici, 1938.

Schaff, Adam. Marksizm a jednostka ludzka. Warszawa: Polskie Wydawnictwo Naukowe, 1965.

Sempołowska, Stefania. Pisma pedagogiczne i oświatowe. Warszawa: Państwowy Instytut Wydawniczy, 1960.

Spasowski, Władysław. Wybór pism, oprac. Władysław Ozga. Warszawa: Książka i Wiedza, 1949.

Spasowski, Władysław. Wybór pism pedagogicznych, oprac. Wacław Wojtyński. Warszawa: Państwowe Zakłady Wydawnictw Szkolnych, 1949.

Spasowski, Władysław. Wyzwolenie człowieka $w$ świetle filozofii, socjologii pracy i wychowania ludzkości. Warszawa: Nakładem F. Hoesicka, 1933.

Spasowski, Władysław. Zasady samoksztatcenia. Warszawa: Wydawnictwo Michata Arcta, 1923.

Spasowski, Władysław. Z.S.R.R. rozbudowa nowego ustroju. Warszawa: Wydawnictwo Jakuba Przeworskiego, 1936.

Walicki, Andrzej. „Rewolucja październikowa jako projekt komunistyczny”. W: Totalitaryzmy XX wieku. Idee, instytucje, interpretacje, red. Wiesław Kozub-Ciembroniewicz, 123-132. Kraków: Wydawnictwo Uniwersytetu Jagiellońskiego, 2010. 